A Semmelweis Egyetem Ortopédiai Klinika közleménye

\title{
Antibiotikum rezisztencia kialakulása MRSA okozta osteomyelitisben Esetismertetés
}

DR. VEZÉR MÁTYÁS, DR. DOMOS GYULA, DR. HORVÁTH NIKOLETTA, DR. KISS SÁNDOR, DR. TEREBESSY TAMÁS, DR. SZÖKE GYÖRGY

\section{ÖSSZEFOGLALÁS}

A szerzők egy területen szerzett MRSA infekció miatt kialakult akut osteomyelitis kórlefolyását mutatják be. A betegség kezelése számos terápiás nehézséget rejt. A kórkép lefolyását jelentősen befolyásolja a szervezet immunológiai állapota, a betegséget előidéző agresszív kórokozó és az alkalmazott terápia. A mútéti beavatkozás szükségességének megítélése, illetve a feltárás időzítése jelenti a legnehezebb döntést. A klinikumban rutinszerűen alkalmazott antibiotikumok mellett előfordulhat a terápia közben fellépő rezisztencia, amelynek felismerése elengedhetetlen a kedvező kimenetelhez és a krónikus osteomyelitis kialakulásának megelőzéséhez.

\section{Kulcsszavak: $\quad$ Antibiotikum kezelés; MRSA; Osteomyelitis;}

M. Vezér, Gy. Domos, N. Horváth, S. Kiss, T. Terebessy, Gy. Szőke: Development of antibiotics resistance in osteomyelitis caused by MRSA. Case report

The authors present the clinical course of acute osteomyelitis due to an MRSA infection in an area. The treatment of the disease has many therapeutic difficulties. The course of the disease is significantly influenced by the status of the immune system, disease-causing aggressive pathogens and the applied therapy. The judgment of the need for surgical intervention and the timing of the exploration represent the most difficult decisions. Whilst taking the antibiotics routinely used in the clinic, resistance during the therapy may occur, the recognition of which is indispensable to the positive outcome and the prevention of chronic osteomyelitis.

Keywords: $\quad$ Anti-bacterial agents - Therapeutic use; Methicillin-Resistant Staphylococcus aureus - Drug effects; Osteomyelitis - Drug therapy; 


\section{BEVEZETÉS}

Az osteomyelitis a csont és a csontvelő fertőzéses gyulladása. Bármely csonton elöfordulhat, de jellegzetes megjelenési helye gyermekek esetében a végtagok hosszú csöves csontjainak metaphysise, míg felnőtteknél általában a csigolyák és a medencecsontok lehetnek érintettek (2). Kialakulásában az exogen fertőzés, illetve a hematogén terjedés játszik szerepet. Ismert fö rizikófaktorai között szerepelnek a trauma és számos immunszuppressziót előidéző állapot. A fertőzést létrehozó baktérium többféle lehet és ezek előfordulási gyakorisága korcsoportonként változik. A kórfolyamat időtartama alapján a betegség akut és krónikus esetekre osztható. Akut formája többnyire típusos tünetekkel jelentkezik, mint a láz, fájdalom, a csontfolyamathoz közel eső ízületben mozgástartomány beszűkülés, azonban előfordulnak nehezebben diagnosztizálható atípusos esetek is (13).

\section{ESETISMERTETÉS}

$\mathrm{Az}$ esetismertetésben szereplő 15 éves fiúgyermek 2018 augusztusában kereste fel háziorvosát két napja tartó magas láz és jobb térdízületi fájdalom miatt. A szakrendelésre irányítás azonnal megtörtént.

$\mathrm{Az}$ anamnézisben a panaszokat megelőző trauma vagy fertőzés nem szerepelt. Az első fizikális vizsgálat során az érintett oldali femur distalis lateralis metaphysise felett duzzanat és bőrpír volt látható, tapintásra a bőr melegnek és érzékenynek bizonyult. Az ízületben 30 fokos extenziós elmaradás volt.

$\mathrm{Az}$ érintett oldali végtagról készített kétirányú röntgenfelvételen nem mutatkoztak egyértelmúen osteomyelitisre utaló jelek. A lateralis condylus physis közeli 1,5-2 cm hosszú szakaszán a corticalis nem volt egyértelmúen követhető. A csont minimálisan transzparensebbnek tűnt és suprapatellarisan enyhe lágyrészdenzitás fokozódás volt látható. A fentiek alapján akut osteomyelitis lehetősége merült fel (1. ábra). A diagnózist az emelkedett CRP (340 mg/l) és VVT süllyedés (68 $\mathrm{mm} / \mathrm{h}$ ), továbbá az MRSA pozitivitást mutató hemokultúra tette teljessé.

A beteg felvételének napján intravénás flucloxacillin terápia kezdődött, amelyet a rezisztencia vizsgálat eredménye alapján intravénás clindamycin-vancomycin kombináció váltott fel.

Egy héttel a betegfelvételt követően készült MRI felvételen a jobb femur distalis metaphysisét érintő osteomyelitis képe volt látható. Megfigyelhetőek voltak a csont mátrixban az egymással összefolyó apró nekrózisok, valamint a kiterjedt subperiostealis folyadékgyülem. A környező lágyrészekben necroticus területek, továbbá a comb területére kiterjedő fasciitis volt látható. A nagymértékű nekrózisra, valamint a nem javuló klinikai állapotra való tekintettel kuratív jellegú mútéti beavatkozásra került sor. A feltárás elsődleges célja a gyulladt terület dekompressziója mellett, az elhalt szövetek és a genny eltávolítása volt (2. ábra).

A mútét első lépéseként a jobb térdízület punkciójával $30 \mathrm{ml}$ serosus folyadék lebocsátása, majd a femur metaphysis területének lateral felőli feltárása történt. Az előemelkedő periosteumot megnyitva bőséges pus ürült, amelyből mintát vettünk. További mintavétel történt a corticalisból és a spongiosából. A tenyésztés a hemokultúra vizsgálat eredményével megegyezően MRSA pozitivitást mutatott. A szövettani vizsgálat gyulladást igazolt.

A beavatkozást követő hetedik naptól intravénás (11 napig), majd orális clyndamicin monoterápia váltotta fel a clyndamycinvancomycin kombinációt (3-4. ábra). Két héttel a mútétet követően a beteg jó általános állapotban, az antibiotikum terápia folytatása mellett otthonába távozhatott. A későbbiekben állapotát ambuláns kontrollvizsgálatokkal ellenőriztük.

Az operáció utáni harmadik héten készült kontroll MRI szerint, az osteomyelitis kisfokú demarkálódást és regressziót mutatott, azonban a femur distalis része körüli tályog újra kialakult (5. ábra). Ebben az időszakban készült röntgenfelvételen a distalis femur teljes felületén csontdestrukció és periostealis reakció ábrázolódott (6. ábra).

A laboratóriumi eredmények tekintetében látható, hogy a C-reaktív protein nagymértékben csökkent a hospitalizáció kezdetéhez képest, a mútét és a célzott antibiotikum kezelésnek köszönhetően (3-4. ábrák). A későbbiekben újbóli enyhe CRP emelkedést tapasztaltunk, változatlan röntgenképek mellett 
(4. ábra). Infektológiai konzílium alapján felvetődött az antibiotikum rezisztencia kialakulásának a lehetősége. Az orális clindamycint sulfamethoxazole-trimethoprim kezelés váltotta fel, melynek eredményeként visszatért a térdfunkció. A továbbiakban recidíva gyanúja nem merült fel.
A tályog újbóli megjelenése a kórokozó agresszivitására utalt, azonban a későbbiekben a laborparaméterek és a klinikai állapot javulása megfelelő indikátorként jelezték a terápia helyes irányát és az antibiotikum váltás szükségességét.

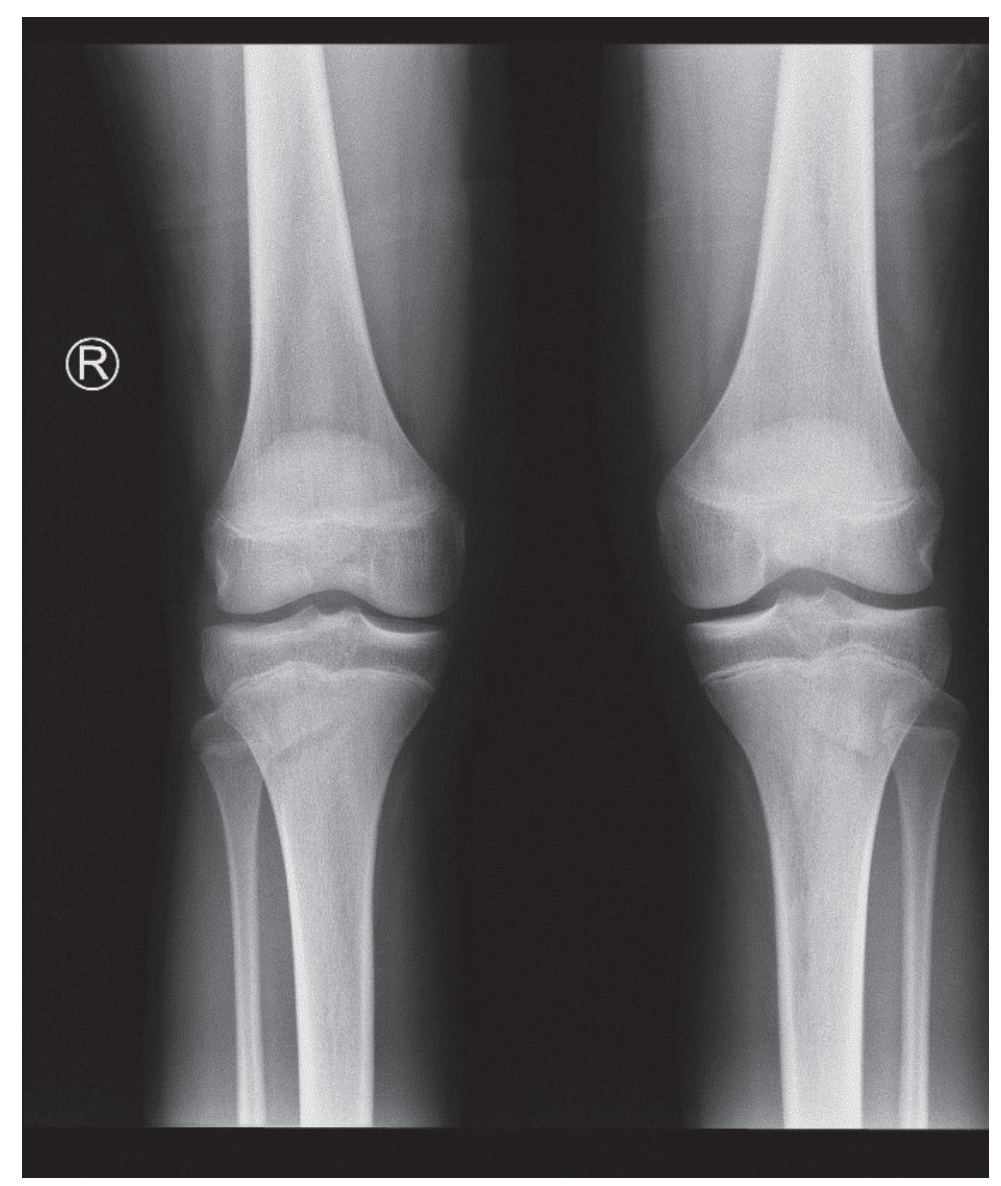

\section{1. ábra}

Térd AP irányú összehasonlító röntgenfelvétele, az akut osteomyelitis kezdeti képével (2018.08.21.) 


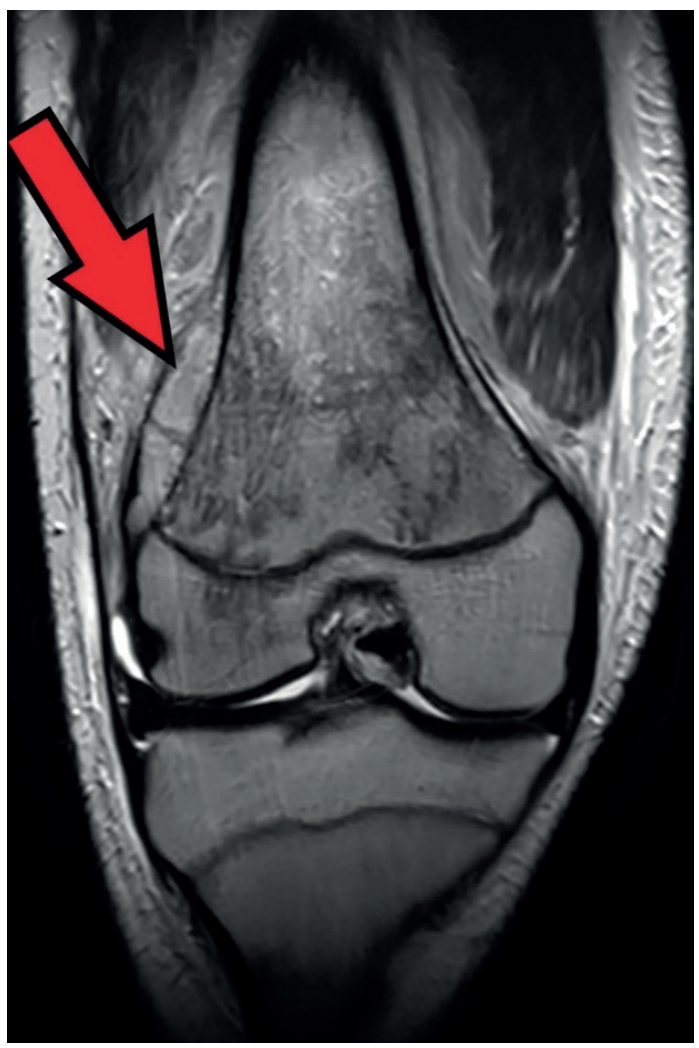

2. ábra

Beavatkozás előtti MRI felvételen ábrázolódó subperiostealis tályog (2018.08.26.)

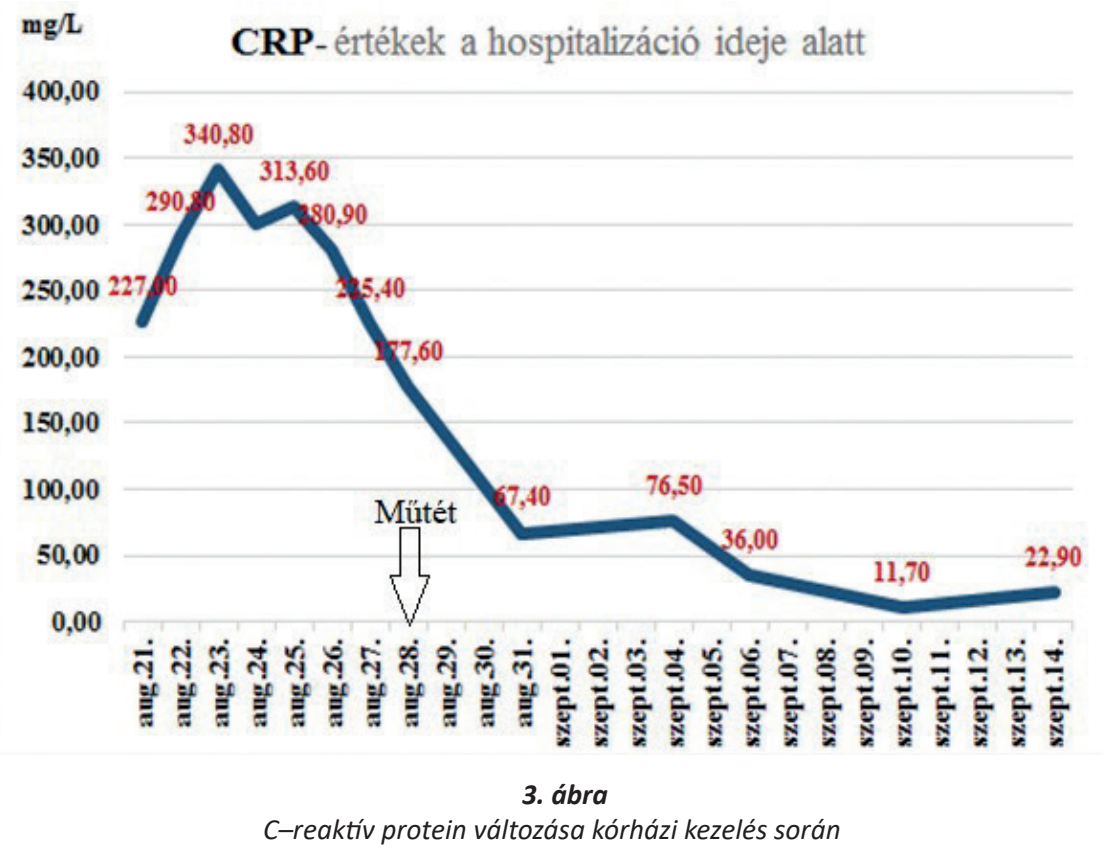




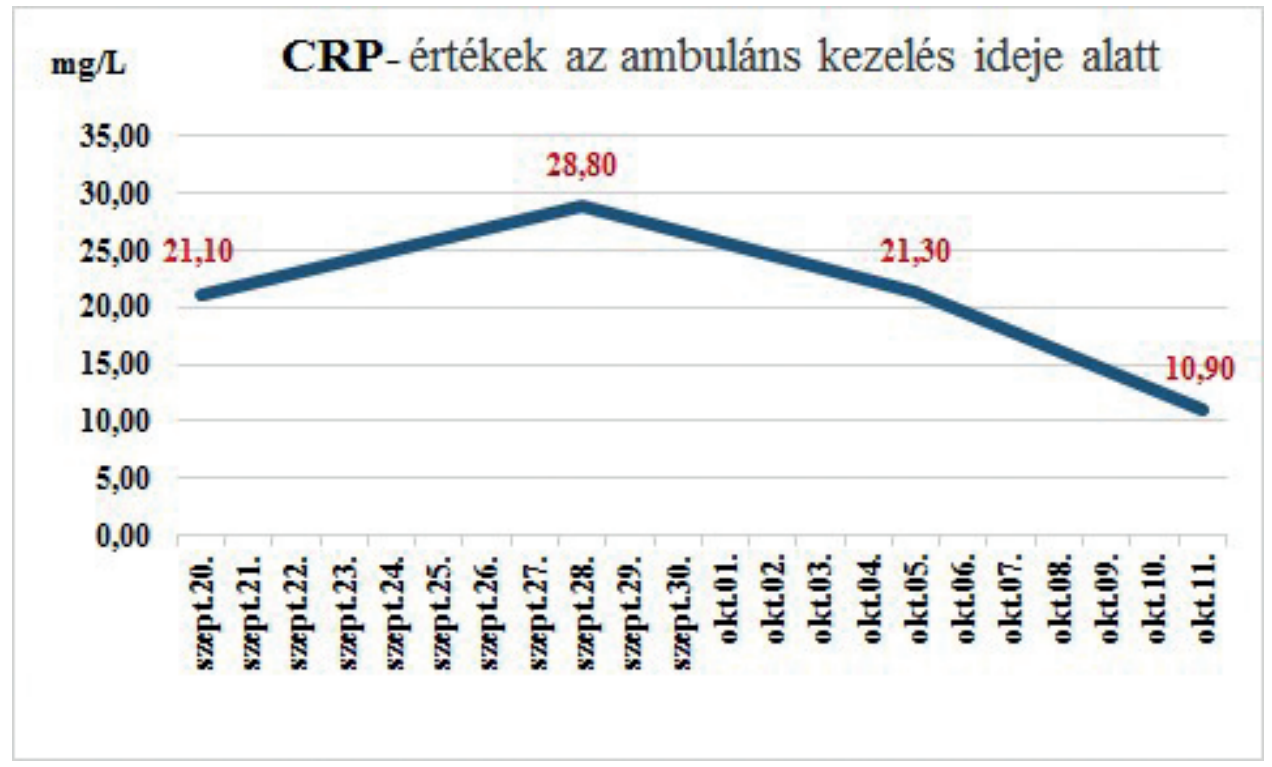

4. ábra

C-reaktiv protein változása ambuláns kezelés alatt

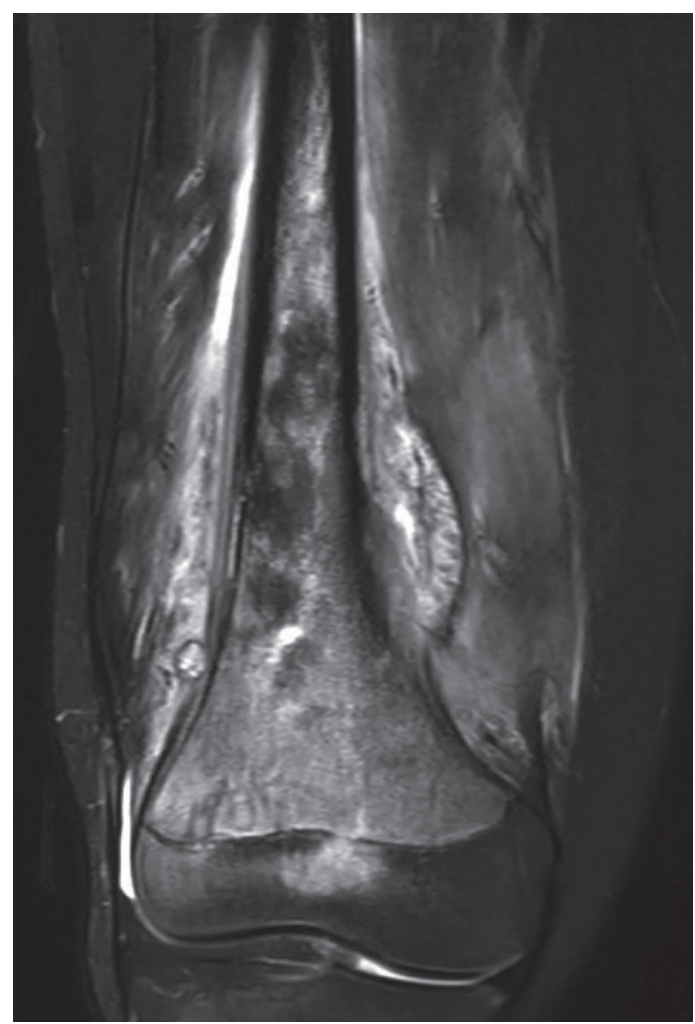

5. ábra

Kontroll MRI felvétel: a dia-metaphysealis régióban elhelyezkedő tályog (2018.09.16.) 


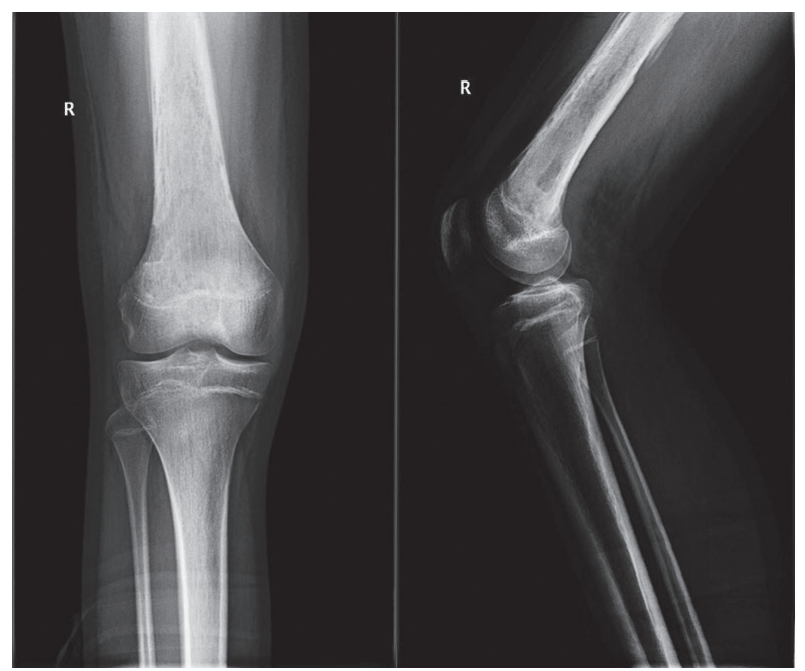

6. ábra

AP röntgen csontdestrukció és periostealis reakció a distalis femuron (2018.09.27.)

\section{MEGBESZÉLÉS}

Az osteomyelitis a csont fertőzéses eredetű gyulladásos megbetegedése. Az infekció kialakulásáért felelős kórokozók hematogén úton, ritkábban közvetlen behatolással (nyílt sebek) juthatnak a szervezetbe (3). Előfordulásának gyakorisága 22/100 000 fő/év. A férfiaknál gyakrabban fordul elő, mint a nőknél, ez az arány korosztályonként változó (9).

$\mathrm{Az}$ összes osteomyelitis megbetegedés körülbelül $80 \%$-ért a Staphylococcus aureus baktérium felelős (4). Az elmúlt évtizedben több epidemiológiai vizsgálat bizonyította az osteomyelitis emelkedő incidenciáját gyermekkorban. Ezzel összefüggésben a Staphylococcus aureus methicillin rezisztens változatának (MRSA) előfordulási gyakorisága is nőtt $(1,6)$. A primer akut hematogén osteomyelitis gyakrabban fordul elő csecsemők és gyermekek körében. Általában a hosszú csöves csontok metaphysisének területén jelentkezik.

A panaszok kezdetben a lokalizált végtagcsont fájdalom, az emelkedett testhőmérséklet, és az érintett terület feletti duzzanat mellett a szomszédos ízületben megjelenő mozgástartomány csökkenés (11). Ezek az akut osteomyelitisre jellemző tünetek esetünkben is megfigyelhetőek voltak.

A röntgenen legkorábban 10-14 nap elteltével ábrázolódik a periosteum megvastagodása vagy előemelkedése, és mindaddig nem látható lítikus elváltozás, amíg a csontmátrix 50-70\%-a nem destruálódott $(7,10)$. Az általunk készített kezdeti röntgenfelvételen ennek megfelelően minimális elváltozás volt látható. Bizonytalan röntgen esetén az MRI segítséget nyújthat a lágyrészek állapotának megítélésében, a csontban pedig t1-es súlyozásban csökkent, míg t2-es súlyozásban emelkedett jelintenzitású velóállomány látható (10). A csont destrukció pontosabban CT felvételeken látható. A háromfázisú csontszcintigráfia a folyamat többgócú megjelenéséről adhat információt.

Általánosan elfogadott tény, hogy akut osteomyelitis esetén, adekvát terápia alkalmazása mellett 48-72 óra elteltével javulás várható a klinikai állapot és a laborparaméterek tekintetében (5). Korai vizsgálataink alkalmával, a javuló laborértékek mellett változatlan klinikai állapotot tapasztaltunk.

$\mathrm{Az}$ akut osteomyelitis terápiájában az egyik legnehezebb döntést a mútéti feltárás szükségességének megítélése jelenti. A CiernyMader-féle klasszifikáció a fertőzés anatómiai elhelyezkedését tekintve négy csoportra osztja az osteomyelitiseket, a konzervatívan kezelendő medullaris és superficialis, valamint a mútéti beavatkozást igénylő lokalizált és diffúz fertőzésekre (3). A beavatkozásra további indikációt jelent a nagy mennyiségű genny jelenléte, a subperiostealis tályog, illetve az eredménytelen antibiotikum kezelés (11). Esetünkben a rossz általános állapot, a fájdalom, valamint az MRI képen ábrázolódó diffúz elhelyezkedésű subperiostealis tályog képezte a beavatkozás indikációját. 
Az ellátás nélkülözhetetlen része a kezdetben intravénásan, majd orálisan alkalmazott célzott antibiotikum adása (2). MRSA infekció kezelését tekintve első vonalbeli szerként intravénás vancomycin használatos (12). A clindamycin az MRSA osteomyelitis kezelésében hatékony szernek bizonyul, mint másodvonalbeli orális szer, azonban használatát limitálja a vele szemben kialakuló rezisztencia lehetősége. Az MRSA rezisztenciája az orális elsővonalbeli sulfamethoxazole-trimethoprim-mel szemben ritkán fordul elő, ezért a gyermekkori osteomyelitis kezelésében hatékonyan alkalmazható (12). Esetünkben a clindamycin alkalmazását szintén korlátozta a vele szemben kialakult feltételezett rezisztencia, ezért a megfelelő kezelést a sulfamethoxazole-trimethoprim terápiára váltás jelentette.
Az utánkövetés tekintetében az antimikrobiális kezelés alatt szorosabb, heti rendszerességű kontroll javasolt, melyek alkalmával We, CRP, vérkép és májfunkciós paraméterek vizsgálata célszerű. Az antimikrobiális kezelés befejezését követően 4 hétig ajánlott a süllyedés és a CRP további ellenőrzése (8).

Összegezve az esetismertetésben felsoroltakat, a kórlefolyást tekintve fontos a kórokozó korai, pontos meghatározása, kezdetben széles spektrumú, majd célzott antibiotikum választása. A legnagyobb terápiás nehézséget a műtéti indikáció jelenti, amely véleményünk szerint esetenként egyedileg mérlegelendő. A rendszeres kontrollvizsgálatok során tapasztalt relapsus esetén gondolnunk kell az antibiotikum rezisztencia kialakulásának lehetőségére is.

\section{IRODALOM}

1. Arnold S. R., Elias D., Buckingham S. C., Thomas E. D., Novais E., Arkader A., Howard C.: Changing patterns of acute hematogenous osteomyelitis and septic arthritis: emergence of community-associated methicillin-resistant Staphylococcus aureus. J. Pediatr. Orthop. 2006. 26: 703-708. https://doi.org/10.1097/01.bpo.0000242431.91489.b4

2. Calhoun J. H., Manring M. M., Shirtliff M.: Osteomyelitis of the long bones. Semin. Plast. Surg. 2009. $23:$ 59-72. https://doi.org/10.1055/s-0029-1214158

3. Cierny G., Mader J. T., Penninck J. J.: A clinical staging system for adult osteomyelitis. Clin. Orthop. Relat. Res. 2003. 414: 7-24. https://doi.org/10.1097/01.blo.0000088564.81746.62

4. Ellington J. K., Harris M., Webb L., Smith B., Smith T., Tan K., Hudson M.: Intracellular Staphylococcus aureus. A mechanism for the indolence of osteomyelitis. J. Bone Joint Surg. Br. 2003. 85. (6): 918-921. https://doi.org/10.1302/0301-620X.85B6.13509

5. Faust S. N., Clark J., Pallett A., Clarke N. M.: Managing bone and joint infection in children. Arch. Dis. Child. 2012. 97: 545553. https://doi.org/10.1136/archdischild-2011-301089

6. Gafur O. A., Copley L. A., Hollmig S. T., Browne R. H., Thornton L. A., Crawford S. E.: The impact of the current epidemiology of pediatric musculoskeletal infection on evaluation and treatment guidelines. J. Pediatr. Orthop. 2008. 28: 777-785. https://doi.org/10.1097/BPO.0b013e318186eb4b

7. Jaramillo D.: Infection: musculoskeletal. Pediatr. Radiol. 2011. 41. Suppl. 1: S127-134. https://doi.org/10.1007/s00247-011-2001-y

8. Kalyoussef S.: Pediatric osteomyelitis follow-up. Ed. Mary L Windle et al. Pediatric Osteomyelitis Follow-up: Further Outpatient Care, Further Inpatient Care, Inpatient \& Outpatient Medications. May 02 2016. Retrieved from: https:/lemedicine.medscape.com/article/967095-followup

9. Kremers H. M., Nwojo M. E., Ransom J. E., Wood-Wentz C. M., Melton L. J., Huddleston P. M.: Trends in the epidemiology of osteomyelitis. J. Bone Joint Surg. 2015. 97. (10): 837-845. https://doi.org/10.2106/JBJS.N.01350

10. Lee Y. J., Sadigh S., Mankad K.:The imaging of osteomyelitis. Quant. Imaging Med. Surg. 2016. 6: $184-198$. https://doi.org/10.21037/aims.2016.04.01

11. Lew D. P., Waldvogel F. A.: Osteomyelitis. N. Engl. J. Med. 1997. 336. (14): 999-1007. https://doi.org/10.1056/NEJM199704033361406

12. Liu C., Bayer A., Cosgrove S. E., Daum R. S., Fridkin S. K., Gorwitz R. J., Kaplan S. L., Karchmer A. W., Levine D. P., Murray B. E., Talan D. A., Chambers H. F., : Clinical practice guidelines by the Infectious Diseases Society of America for the treatment of methicillin-resistant Staphylococcus aureus infections in adults and children. Clin. Infect. Dis. 2011. 52. (3): e18-55. https://doi.org/10.1093/cid/ciq146

13. Weintrub P. S.: TMP-SMX is another option for treatment of acute osteomyelitis. Reviewing Messina AF et al. Pediatr Infect Dis J. 2011. Dec NEJM Journal Watch. Retrieved from: https://www.jwatch.org/pa201112210000003/2011/12/21/tmp-smx-another-option-treatment-acute

\section{Dr. Vezér Mátyás}

E-mail: drvezermatyas@gmail.com

Mobil: +36203916005 